\title{
Dynamika współczesności w zwierciadle leksyki
}

\author{
Ваня Зидарова, Динамика и иновации \\ в лексикалната система на българския език. \\ Пловдив: Коала прес, 2019, 228 s.
}

\begin{abstract}
Długosz Natalia, Dynamika wspótczesności w zwierciadle leksyki (The Dynamic of the Present Day in the Lexicon Mirror). "Poznańskie Studia Slawistyczne" 19. Poznań 2020. Publishing House of the Poznań Society for the Advancement of the Arts and Sciences, Adam Mickiewicz University, pp. 421-427. ISSN 2084-3011.

This review is a short presentation and an analysis of the book Динамика и иноваиии в лексикалната система на българския език, published in 2019 in Plovdiv. The book consists of nine parts, each dealing with a different type of linguistic processes (archaisation, terminologisation and determinologisation, lexicalisation, univerbation, neologisation, internationalisation) occurring in the lexical system of contemporary Bulgarian. Linguistic changes in the lexical sphere are presented in the context of dynamic changes in the methods of communication, determined by non-linguistic reality. The monograph deals with new vocabulary, from the end of the $20^{\text {th }}$ century to the present day. It contains a synthetic review of certain positions within the scope of the discussed linguistic processes. An effort was also made to organise the terminology used in Bulgarian linguistic studies. The advantage of the monograph resides in the original propositions for the interpretation of individual phenomena and the author's own propositions for definitions. What makes the publication particularly interesting is the presentation of an experimental study in the field of examining language competence and language memory of those Bulgarian language users who represent the generation of today's students.
\end{abstract}

KEYwORDs: dynamics of language processes; lexical innovations; Bulgarian language

W ostatnich miesiącach 2019 roku na bułgarskim rynku wydawniczym ukazała się książka autorstwa Wani Zidarowej zatytułowana Динамика и иновации в лексикалната система на българския език. Warto zwrócić na nią uwagę, ponieważ dotyka aktualnej problematyki. A mianowicie 
autorka pisze o dynamicznej rzeczywistości językowej i wielopłaszczyznowym jej odzwierciedleniu zwłaszcza w warstwie leksykalnej współczesnej bułgarszczyzny. Bułgarskiej językoznawczyni towarzyszy niezłomne przekonanie o ekstralingwistycznej genezie wielu modyfikacji wewnątrz języka. Na kartach książki wyraźnie akcentuje, że u źródła dziejących się na naszych oczach zjawisk natury językowej znajdują się dynamiczne zmiany w sposobach komunikowania, te z kolei są determinowane rzeczywistością pozajęzykową. Wszystkie procesy językowe zostają zatem ukontekstowione, a przyczynę zmian upatruje się nie tylko w demokratyzacji, globalizacji i technicyzacji życia społecznego, ale także w konsumizacji ludzkich zachowań, bezrefleksyjnym przejmowaniu lansowanych w mediach (różnego typu, w tym w mediach społecznościowych) wzorców i mód. Takie ujęcie problematyki niewątpliwie ją uatrakcyjnia, czyniąc bardziej interesującą dla potencjalnego odbiorcy.

Monografia płowdiwskiej badaczki stanowi swego rodzaju kompendium wiedzy na temat zjawisk i zmian, jakie zachodzą w słownictwie języka bułgarskiego od końca XX wieku po dzień dzisiejszy. Omówione zostały procesy archaizacji, ale i przywrócenia do użycia słownictwa wcześniej pasywnego, terminologizacji, ale i determinologizacji, poruszono kwestię leksykalizacji, neologizacji, internacjonalizacji. Osobne miejsce w opracowaniu zajmują zagadnienia związane z uniwerbacją w języku. Omówione zostały także wyłaniające się z praktyki językowej tendencje leżące u podstaw zmian w zasobie słownictwa i postrzegane jako czynnik decydujący o leksykalnym zróżnicowaniu współczesnej bułgarszczyzny. Interesujące wydaje się zwłaszcza ujęcie najnowszych tendencji w rozwoju współczesnego bułgarskiego systemu leksykalnego w kontekście strategii komunikacyjnych dyskursu publicystycznego. Autorka dokonuje syntetycznego przeglądu stanowisk w zakresie omawianych procesów oraz podejmuje nieoceniony wysiłek uporządkowania terminologii stosowanej w bułgarskich opracowaniach lingwistycznych. Nie tylko dostrzega potrzebę doprecyzowania wielu terminów, w tym sposobów rozróżniania i rozumienia określonych zjawisk, ale także przedstawia własne propozycje definicji.

Nieschematyczna wydaje się już sama koncepcja podziału zmian leksykalnych na dwie grupy:

- mikroewolucję słownictwa, która obejmuje zmiany w zakresie jednostki leksykalnej bazujące na procesie derywacji semantycznej, takie 
jak np. uniwerbacja, leksykalizacja, zmiany funkcjonalne w użyciu leksemów;

- makroewolucję słownictwa odnoszącą się do całego systemu leksykalnego danego języka lub do wyodrębnionych grup słownictwa, jak np. archaizacja, aktualizacja znaczenia, neologizacja, terminologizacja itd. (Зидарова, 2019, 39).

Przykładem konsekwentnie przeprowadzonego przez lingwistkę wyboru terminologicznego jest wyraźne wydzielenie zakresu terminów uniwerbacja (универбация) i uniwerbizacja (универбизация), których zamienne użycie wprowadza wiele zamieszania nie tylko w opracowaniach bułgarskojęzycznych. Zidarowa zaznacza, że przez uniwerbację rozumie „metodę derywacyjną, w której rezultacie otrzymujemy pojedynczą jednostkę leksykalną powstałą na bazie polileksykalnego kompleksu [przeł. N. D.]" (Зидарова, 2019, 84). Natomiast uniwerbizacja to pojęcie w stosunku do uniwerbacji nadrzędne, hiperonimiczne i oznaczające pewną uniwersalną, ogólnojęzykową tendencję do ekonomii formy przy jednoczesnym zachowaniu maksymalnego zakresu znaczeniowego. W tym i kilku innych przypadkach zaakcentowanie potrzeby ujednolicenia i doprecyzowania terminologii językoznawczej w zakresie opisu leksykograficznego nabiera ważności zwłaszcza w kontekście wielości stosowanych aktualnie instrumentariów badawczych.

O wartości książki stanowi nie tylko nowatorski, niestandardowy sposób opisywania zjawisk już znanych, ale dostrzeżenie i zaakcentowanie tych procesów, które do tej pory nie doczekały się kompleksowych opracowań. Mam na myśli choćby reanimację słownictwa, pod którym to terminem badaczka rozumie występowanie na powrót w zdarzeniach użycia językowego leksemów do tej pory należących do zasobów leksyki pasywnej lub leksyki o ograniczonym zasięgu. W tym miejscu wskazuje m.in. na turcyzmy w języku bułgarskiej publicystyki. Leksyka ta, ze względu na panujące tendencje purystyczne, przez długi czas należała do słownictwa niezalecanego (mówi się nawet o scholastycznym języku mediów okresu 1944-1989), posiadała też najczęściej silnie pejoratywne nacechowanie stylistyczne i wręcz stygmatyzowała nadawcę wypowiedzi. W okresie przemian ustrojowych po 1989 roku turcyzmy aktywizują się ze zdwojoną siłą w języku mediów, z czasem stając się swego rodzaju manierą, pełniącą funkcję stricte pragmatyczną - przyciągania uwagi odbiorcy. 
W swoim studium Zidarowa wielokrotnie podkreśla złożony i niezwykle dynamiczny charakter zjawisk językowych. Zaznacza, że różnego typu zmiany mikroewolucyjne mogą następować po sobie - ustępować, by potem znów powracać, co powoduje, że formalnie ta sama jednostka leksykalna niekiedy nawet $w$ niezbyt odległych odstępach czasowych (może to być kwestia jednego pokolenia lub nawet dziesięciolecia) z aktywnej i aktualnej przechodzi do zasobu słownictwa pasywnego i niezrozumiałego dla młodszych użytkowników języka.

W kontekście powyższych obserwacji na szczególną uwagę zasługuje wykonane i opisane w książce badanie eksperymentalne polegające na przeprowadzeniu wśród 100 respondentów ankiet dotyczących znaczenia dwunastu wyrazów. Grupa respondentów (studenci Uniwersytetu Płowdiwskiego urodzeni w 1999 roku) miała za zadanie wyjaśnić znaczenie wybranych leksemów. Należą one częściowo do pasywnych zasobów słownika, tj. w zbiorze znalazły się archaizmy, historyzmy oraz polisemantyzmy, w których jedno ze znaczeń uległo archaizacji. Mowa o leksemach: пионер, бригада, Комсомол, ТКЗС, съботник, казарма, милиционер, теляк, чавдарче, звеновод, петилетка. Jak zaznacza Zidarowa, celem eksperymentu było zbadanie nie tylko kompetencji językowej respondentów, ale także ich ,językowej pamięci” (Зидарова, 2019, 53). Dane ankietowe dostarczyły interesujących rezultatów i unaoczniły proces postępującej semantycznej archaizacji, a niekiedy neologizacji wybranych jednostek leksykalnych. Jednak sposób prezentacji wyników zawiera pewne niedociągnięcie, które u młodszego odbiorcy może powodować zupełny brak zrozumienia tak przeprowadzonej operacji. Otóż nie wskazuje się w żadnym miejscu słownikowych znaczeń poddanych analizie dwunastu wyrazów. Zawartość semantyczna słów ma prawo nie być i, jak zresztą dowodzi sam eksperyment, najczęściej nie jest znana pokoleniu dzisiejszych studentów.

Pewne nieścisłości pojawiają się także w innych miejscach w książce. Dla przykładu, omawiając tendencję do leksykalizacji skrótowców, badaczka zarzuca autorom Słownika nowych wyrazów i znaczeń w języku bułgarskim (Пернишка, Благоева, Колковска, 2001) nieuwzględnienie w opracowaniu jednostek, które w bułgarszczyźnie mają charakter już ustabilizowany, nр. джиесем, джипи, джипиес, диджей. Nie jest zrozumiałe jednak, dlaczego Zidarowa odnosi się tutaj do wydania słownika 
z 2001 roku, a nie uwzględnia wydania z 2010 roku uzupełnionego o nowe leksemy, mimo że właśnie na to wydanie słownika powołuje się w innych miejscach w tekście (cf. Зидарова, 2019, 123, 132 i in.). Z reguły jednak ilustracja przedstawionych zjawisk językowych związanych z wszelkiej maści zmianami w obrębie systemu leksykalnego współczesnej bułgarszczyzny jest trafna i przekonująca. Na docenienie zasługuje także umiejętność porządkowania niełatwych zagadnień teoretycznych i przybliżenie ich czytelnikowi w jasnym i potoczystym wywodzie.

Godna pochwalenia jest przyjęta przez badaczkę procedura obrazowania przedstawianych zjawisk językowych bogatym zasobem przykładów. Zwraca uwagę też fakt, że dokonywana interpretacja prezentowanego materiału językowego z reguły nie budzi zastrzeżeń. Choć w jednym miejscu nie mogę się z nią zgodzić. Chodzi mianowicie o twierdzenie, że wyrazy złożone z pierwszym komponentem obcym (typu еко-, евро-, био- itp.) są przezroczyste semantycznie, co zawdzięczają znaczeniu pełnej formy wyrazu, od którego pochodzą (Зидарова, 2019, 94). Badania dowodzą, że właśnie te serie wyrazów wykazują właściwość wręcz przeciwną - cechuje je wysoki stopień semantycznego niedookreślenia. Rozpatrywane w kontekstach użycia językowego stają się znakami silnie zdeterminowanymi i, co więcej, najczęściej semantyczna pojemność powtarzanego w wielu wyrazach złożonych członu pozwala na dowolne modyfikowanie znaczenia całych struktur. Udowadniam to wielokrotnie w książce $O$ znakach ubezwłasnowolniownych, czyli o nowych polskich i bułgarskich compositach bezafiksalnych $w$ medialnym dyskursie publicystycznym (2017).

Badaczka jest znakomicie zaznajomiona z najnowszymi osiągnięciami W zakresie prezentowanej problematyki i świetnie obeznana z literaturą przedmiotu w języku bułgarskim i rosyjskim. Umiejętnie prezentuje ważne ujęcia teoretyczne, przybliżając czytelnikowi koncepcje pochodzące z różnych szkół lingwistycznych, niejednokrotnie podejmując dyskusję $\mathrm{z}$ największymi autorytetami w dziedzinie. Z własnej perspektywy, bułgarystyki zagranicznej, muszę przyznać, że jeśli czegoś mi zabrakło, to może nieco odmiennego od prezentowanych tu osiągnięć szkół sofijskiej, płowdiwskiej i po części moskiewskiej spojrzenia polskich bułgarystów na zachodzące w języku bułgarskim ostatnich dziesięcioleci zmiany leksykalne. Dużą korzyścią dla odbiorców książki byłoby uwzględnienie poglądów na temat terminologizacji i determinologizacji słownictwa w języku 
bułgarskim, jakie prezentują Julia Mazurkiewicz-Sułkowska (2014) i Iliana Genew-Puhalewa (2015). W kontekście dynamicznych zmian zachodzących w systemie leksykalnym bułgarszczyzny warta podjęcia byłaby zwłaszcza interesująca teza o „europejskiej izosemii międzyjęzykowej”, którą Genew-Puhalewa postrzega jako rezultat unifikacyjnego wpływu angielszczyzny (języka o wysokim prestiżu) na inne języki Unii (Генев-Пухалева, 2015, 188). Zjawisko to bowiem dotyczy także leksyki współczesnego języka bułgarskiego i to w największym stopniu.

Wartością książki jest niewątpliwie podkreślenie mnogości procesów językowych, jakie zachodzą w systemie leksykalnym współczesnej bułgarszczyzny, dostrzeżenie ich różnorodności, wielokierunkowości oraz tempa. Poza wspomnianymi wcześniej zjawiskami Zidarowa porusza m.in. kwestię adaptacji lawinowo napływających do języka anglicyzmów (mowa zarówno o adaptacji fonetycznej, jak i gramatycznej), wskazuje na aktualne zjawisko konkurowania form rodzimych i obcych, brak konsekwentnych zasad transliteracji wyrazów obcych w praktyce językowej (np. niejednolita adaptacja fonetyczna leksemów z sufikami -ir, -er, -ar, -or), zwraca uwagę na przemieszanie słownictwa z różnych rejestrów i odmian, a nawet alfabetów (łacinka vs cyrylica) w strategiach komunikacyjnych stosowanych w mediach masowego przekazu, a także na przykład na rywalizujące ze sobą tendencje (autochtonizacja vs internacjonalizacja) przy nadawaniu imion nowonarodzonym bułgarskim dzieciom.

Recenzowana monografia odznacza się przystępnością, a ze względu na swój nieco skryptowy i syntetyczny charakter wydaje się szczególnie przydatna w procesie dydaktycznym nie tylko dla przyszłych bułgarystów, ale także dla studentów innych filologii słowiańskich, ponieważ wiele z omawianych tu zmian i zjawisk dotyczy większości języków słowiańskich. Bogato reprezentowany w pracy materiał językowy dodatkowo uwypukla jej walory zarówno praktyczne, jak i dydaktyczne. Oprócz tego opracowanie dostarcza wiedzy na temat bardzo aktualnych problemów współczesnego językoznawstwa oraz sygnalizuje i odnotowuje zjawiska zupełnie nowe, dotąd nieopisane, inspirując tym samym do pogłębiania obserwacji i poszukiwania nowych narzędzi badawczych. 


\section{Literatura}

Długosz, N. (2017). O znakach ubezwłasnowolniownych, czyli o nowych polskich i butgarskich compositach bezafiksalnych w medialnym dyskursie publicystycznym. Poznań: Wydawnictwo Naukowe Uniwersytetu im. Adama Mickiewicza.

Genew-Puhalewa, I. (2015). Терминология на Европейския съюз. Съпоставка на българската, гръиката, полската и английската терминология на правото на околната среда. Katowice: Wydawnictwo Uniwersytetu Śląskiego.

Mazurkiewicz-Sułkowska, J. (2014). Stowiańska terminologia techniczna na materiale polskim, rosyjskim i bułgarskim. Łódź: Wydawnictwo Uniwersytetu Łódzkiego. https://doi.org/10.18778/7969-306-1.

Зидарова, В. (2019). Динамика и иноваџии в лексикалната система на българския език. Пловдив: Коала прес.

Пернишка, Е., Благоева, Д., Колковска, С. (2001). Речник на новите думи и значения в българския език. София: Наука и изкуство.

Пернишка, Е., Благоева, Д., Колковска, С. (2010). Речник на новите думи и значения в българския език. София: Наука и изкуство.

[Zidarova, V. (2019). Dinamika i inovacii v leksikalnata sistema na b"lgarckiâ ezik. Plovdiv: Koala pres.

Perniška, E. Blagoeva, D., Kolkovska, S. (2001). Rečnik na novite dumi i značeniâ $v$ b"lgarskiâ ezik. Sofiâ: Nauka i izkustvo.

Perniška, E. Blagoeva, D., Kolkovska, S. (2010). Rečnik na novite dumi i značeniâ $v$ b"lgarskiâ ezik. Sofiâ: Nauka i izkustvo]. 